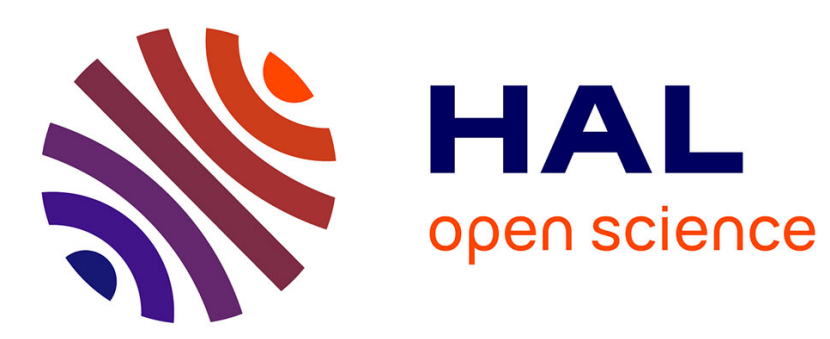

\title{
Vitamin E intestinal absorption: Regulation of membrane transport across the enterocyte
}

Emmanuelle Reboul

\section{To cite this version:}

Emmanuelle Reboul. Vitamin E intestinal absorption: Regulation of membrane transport across the enterocyte. IUBMB Life, 2019, 71 (4), pp.416-423. 10.1002/iub.1955 . hal-02022877

\section{HAL Id: hal-02022877 \\ https://hal-amu.archives-ouvertes.fr/hal-02022877}

Submitted on 18 Feb 2019

HAL is a multi-disciplinary open access archive for the deposit and dissemination of scientific research documents, whether they are published or not. The documents may come from teaching and research institutions in France or abroad, or from public or private research centers.
L'archive ouverte pluridisciplinaire HAL, est destinée au dépôt et à la diffusion de documents scientifiques de niveau recherche, publiés ou non, émanant des établissements d'enseignement et de recherche français ou étrangers, des laboratoires publics ou privés. 


\section{Vitamin E intestinal absorption: regulation of membrane transport across the enterocyte}

Emmanuelle Reboul

Aix Marseille Univ, INSERM, INRA, C2VN, Marseille, France.

Emmanuelle.Reboul@univ-amu.fr; Tel. :+33-049-1324-278 


\begin{abstract}
Vitamin E is an essential molecule for our development and health. It has long been thought that it was absorbed and transported through cellular membranes by a passive diffusion process. However, data obtained during the past 15 years showed that its absorption is actually mediated, at least in part, by cholesterol membrane transporters including the Scavenger Receptor Class B type 1 (SR-BI), CD36 molecule (CD36/SRB2), NPC1 like transporter 1 (NPC1L1) and ATP-binding cassettes A1 and G1 (ABCA1 and ABCG1). This review focuses on the absorption process of vitamin E across the enterocyte. A special attention is given to the regulation of this process, including the possible competition with other fat-soluble micronutrients, and the modulation of transporter expressions. Overall, recent results noticeably increased the comprehension of vitamin E intestinal transport, but additional investigations are still required to fully appreciate the mechanisms governing vitamin E bioavailability.
\end{abstract}

Keywords: tocopherol; intestine; mixed micelles; membrane transporters; uptake; chylomicrons; HDL; fat-soluble vitamins, bioavailability, competition. 


\section{Introduction}

The vitamin E family includes four tocopherols and four tocotrienols (Figure 1) originating from plants and other photosynthetic organisms (1). The main vitamin E sources are vegetable oils such as sunflower oil, and nuts such as almond (2). The human diet mainly provides RRR- $\alpha$-tocopherol in Europe (3), while RRR- $\gamma$-tocopherol is highly consumed in the US (4). RRR- $\alpha$-tocopherol is also the main vitamer present in human blood and tissues (3). In this review, we will thus mainly focus on both $\alpha$-tocopherol and $\gamma$-tocopherol.

Vitamin E has primarily been identified as an essential factor to restore fertility in deficient female rats (3). Further investigations showed that vitamin E was also a potent antioxidant (3), as well a key molecule in the modulation of signal transduction and gene expression in the context of inflammation and immune system disorders (5). However, dietary surveys highlighted that a significant part of the population in Europe and in the US did not cover the Recommended Dietary Allowance for vitamin E (6). These alarming conclusions strengthen the major interest of promoting vitamin E bioavailability from foods and to fully understand the molecular mechanisms governing its intestinal absorption.

During the digestion process, vitamin E is extracted from its food matrix, dissolved in the fat phase of the bolus at the gastric level and finally incorporated into mixed micelles with other lipid hydrolysis products during duodenal digestion (see for review (7)). Mixed micelles then diffuse through the unstirred water layer of the glycocalix area to approach the apical membrane of the enterocytes, i.e. the brush border membrane. Vitamin E absorption has long been considered to occur by passive diffusion because it was i) independent of ATP, and ii) linear up to fairly high concentrations (1.2 mM) in rat intestine (8). However, these data were conflicting with other results showing that vitamin E 
postprandial responses after a tocopherol load were highly variable in humans (9).

Vitamin E transport mechanisms in the intestine have thus been reinvestigated recently.

\section{Vitamin E transport across the enterocyte (Figure 2)}

Vitamin E uptake across the brush border membrane: role of SR-BI, CD36 and NPC1L1

In 2006, we showed for the first time that both $\alpha$ - and $\gamma$-tocopherol intestinal uptake was facilitated by SR-BI (scavenger receptor class B type I) (10). This observation is not surprising because SR-BI contributes to vitamin E uptake in liver cells (11), porcine brain (12), rat retina (13) and pneumocytes (14). Furthermore, vitamin E metabolism is altered in SR-BI-deficient mice (15) and a protein analog to SR-BI can mediate vitamin E uptake in Drosophila (16). SR-BI was later confirmed to be a major protein in vitamin E intestinal uptake, at least in Caco-2 cell and mouse models (17), as well as in the uptake of fatsoluble micronutrients and phytochemicals in general (7). Interestingly, SR-BI was also shown to mediate vitamin E efflux from the cytosolic compartment of Caco-2 cells to the apical medium, suggesting a potential regulatory role of this protein in vitamin E cellular concentrations (10). The molecular mechanisms underlying vitamin E transport through SR-BI are still unknown. SR-BI was primarily shown to selectively mediate the uptake of $\alpha$-tocopherol from HDL (12), which suggests a direct interaction with this ligand.

However, SR-BI has also been shown to traffic in clathrin-coated lipid vesicles after a lipid load (18), and we demonstrated that SR-BI extracellular loop could bind mixed micelles (19). Finally, SR-BI has recently been described as an intestinal lipid sensor (20), and it appeared to be a modulator of chylomicron secretion (21). These last results suggest that SR-BI may actually promote lipid flux through the enterocyte and thus indirectly enhance 
vitamin $\mathrm{E}$ absorption. Further research is therefore required to understand the nature of interactions between SR-BI and vitamin E.

We later showed that besides its ability to transport carotenoids (22) and possibly vitamin D (23) and K (24), intestinal CD36 (CD36 molecule) could contribute to tocopherol absorption process (25). However, despite the fact that the extracellular loop of this protein could bind mixed micelles (19) and that CD36 was clearly involved in vitamin E uptake in vitro, its effect on vitamin $\mathrm{E}$ absorption in vivo in mice was rather due to its impact on lipid general absorption process. Conversely to what was expected, CD36-deficient mice showed an accumulation of plasma vitamin E during the postprandial state, due to a defect of clearance of the produced chylomicrons (25).

Finally, by using both Caco-2 and rodent models, it was shown that the major intestinal cholesterol transporter, i.e. NPC1L1 (NPC1 like intracellular cholesterol transporter 1) was another contributor to $\alpha$-tocopherol absorption $(26,17)$. Accordingly, the overexpression in Caco-2 cells of clustered variants of NPC1L1, presenting either a decreased expression level, an altered subcellular localization or a lower intrinsic activity compared with wildtype NPC1L1, led to a decreased vitamin E absorption (27). Additionally, it was recently revealed in transfected cells that $\alpha$-tocopherol could compete with cholesterol to bind to the NPC1L1-N terminal domain. This interaction promoted NPC1L1 endocytosis, which may in turn enhance lipid and vitamin E transport in clathrin-coated lipid vesicles (28). As expected ezetimibe, which is a potent inhibitor of NPC1L1, can reduce vitamin E absorption in vivo in rats (26). As recent data also suggested that Orlistat could also inhibit NPC1L1 functioning (29), further research is needed to evaluate the long-term effects of these drugs on vitamin E status in humans. 
Vitamin E basolateral secretion from the enterocyte: chylomicron and intestinal HDL pathways Vitamin E trafficking across the enterocyte is poorly understood. Due to its lipophilic nature, vitamin E should likely be targeted to cytosolic lipid droplets or organelle membranes after absorption. Indeed, a recent work showed that in cultured liver cells, both $\alpha$ - and $\gamma$-tocopherol were associated with lysosomes and endoplasmic reticulum membrane (30). It may also traffic bound to binding proteins, the best candidate being Sec14p-like proteins TAP1, 2 and 3 (31). Vitamin E is then packed into chylomicrons without esterification in the Golgi apparatus to be released to the lymph (7). Besides, a non-apoB pathway involving ABCA1 (ATB-binding cassette A1) $(32,33)$ and maybe ABCG1 (34) has been demonstrated in mice and in Caco-2 cells. These data are supported by the fact that ABCA1 has been described as an important vitamin E exporter in several cell types including human fibroblasts, mouse macrophages (35) and liver cells (36). Similarly, ABCG1 has also been involved in vitamin E membrane transport in transfected CHO cells, Hep3B hepatocytes and THP-1 macrophages, and vitamin E metabolism was abnormal in ABCG1-deficient mice (37). The mechanisms responsible for vitamin $\mathrm{E}$ transport via $\mathrm{ABC}$ transporters have not been resolved yet, but we propose a process similar to the one suggested for cholesterol. It is believed that ABCA1 acts like a flippase that induces the rearrangement of plasma membrane phospholipids, thus favoring the anchoring of apo A-I (apolipoprotein A-I) to the cellular membrane. Once bound to the membrane, apoA-I can then be loaded with phospholipids and cholesterol, allowing their removal from the cell (38).

\section{Vitamin E intestinal absorption sites and competition for absorption with other}

\section{(micro)nutrients}


The assumption that vitamin E was absorbed in the proximal or mid-intestine (39) has recently been challenged by the observation that after a gavage, vitamin E accumulation in intestinal mucosa was mainly located in the distal part of mouse small intestine, i.e., in the distal jejunum and the ileum $(17,40)$. This seems contradictory with duodenal or jejunal expression of SR-BI (41), CD36 (42) and NPC1L1 (43). We could hypothesize a better clearance of vitamin E from enterocyte cytosol in the upper part of the intestine compared to the distal part. However, this is unlikely because we would have observed a similar phenomenon for other fat-soluble vitamins, and this is not the case for vitamin A, which accumulates in the proximal intestine as expected (40). In fact, the expression of these 3 proteins is highly variable along the intestine and they can be highly expressed in the ileum (44). Moreover, although more expressed in the duodenum, SR-BI is present in significant amount on the basolateral membrane of the ileum enterocytes (45), where it may play a role in vitamin E release to the lymph or the blood compartments.

The existence of membrane proteins facilitating vitamin $\mathrm{E}$ transport in the enterocyte raises the possibility of a discrimination between the different vitamers, a saturation of absorption, as well as possible competitions for absorption between the different ligands. Interestingly, the intestine does not discriminate between vitamers $(46,10)$ or stereoisomers (47) of vitamin E. However, a higher absorption of $\alpha$-tocopherol compared to $\gamma$ - and $\delta$-forms has been observed in in lymph-cannulated rats (48), likely due to a preferential metabolization and excretion of $\gamma$ - and $\delta$-tocopherols (49). Vitamin E absorption efficiency assessed with deuterium- or ${ }^{14} \mathrm{C}$-labeled vitamin $\mathrm{E}$ ranged from 10 to $81 \%$ in humans $(50,51)$. This high variability may be partly linked to factors related to the food matrix used to provide vitamin E (apples vs milk). Among the dietary factors negatively affecting vitamin E absorption (see for review (7)), we showed in Caco-2 cells 
that $\alpha$-tocopherol could compete for absorption with cholesterol, as well as with $\gamma$ tocopherol, vitamin A, D, K and carotenoids (10, 22, 24). Except for vitamin A, these competitions are likely due to shared uptake routes involving common transporters. Regarding vitamin $\mathrm{A}$, it has been hypothesized that vitamin $\mathrm{E}$ was protecting retinol (preformed vitamin A) from luminal oxidation, leading to a degradation and thus a reduced absorption of vitamin E (52). Phytosterols may also inhibit vitamin E absorption in normocholesterolemic patients (53) through similar mechanisms than the ones leading to reduce cholesterol absorption, i.e. a competition for incorporation into mixed micelles and a reduction of uptake by the enterocyte. Finally, the flavanone naringenin altered vitamin E uptake by Caco-2 cell monolayers (54), probably by interfering with membrane transporter functioning, as previously shown with digestive enzymes (55).

Finally, the identification of membrane proteins facilitating vitamin E uptake does not rule out the possibility of a partial transport by passive diffusion. Indeed, we previously showed that vitamin D uptake was facilitated by membrane transporters at dietary doses while it was driven by passive diffusion at higher doses (23). Passive diffusion contribution may be more or less important along the duodenal-ileal axis, which would partly explain why transporter expressions do not correlate with vitamin E accumulation in mouse intestinal mucosa.

\section{Regulation of vitamin E membrane transport in the intestine}

The fact that vitamin E transport is, directly or indirectly mediated by lipid transporters, raise two additional questions: "Can vitamin E regulate the expressions of these transporters and thus impact on both its own transport and other lipid transport?" and 
“Can other factors, by regulating the expression of these transporters, modulate vitamin E fluxes in the intestine?"

\section{Vitamin E and SR-BI regulation}

Vitamin E effect on intestinal SR-BI expression has not been investigated yet. However, it is worth to mention that vitamin E-depleted diet induced a drastic increase in SR-BI expression in rat liver, while HepG2 incubation with vitamin E could conversely reduce SR-BI expression, putatively through a PKC (protein kinase C)-dependent signaling pathway (56). Such regulation may also occur in the enterocyte.

Besides, oleic acid and ecosapentaenoic acid (EPA) were shown to moderately increase SRBI expression in Caco-2 cells (57), while ezetimibe (58) and chokeberry polyphenols (59) could decrease it. Using both human cell and mouse models, it was also shown that SR-BI expression was subject to control by retinoid signaling via the intestinal transcription factor ISX, which can repress its expression (60). Conversely, insulin resistance state increased SR-BI intestinal expression in hamsters (61). Finally, SR-BI post-transcriptional regulation was shown to be dependent on bile component delivery to the intestine (i.e. in cholestasis conditions), bile salts leading to an increased in SR-BI expression in rodent intestines (62). All these factors may thus modulate vitamin $\mathrm{E}$ absorption via their effects on intestinal SR-BI regulation (Table 1).

\section{Vitamin E and CD36 regulation}

Vitamin E effect on transcriptional regulation of CD36 has first been described about 20 years ago (63). If no data are available on such regulation at the intestinal level, it was consistently shown that vitamin E could inhibit CD36 expression in aortic smooth muscle 
cells (64), human macrophages (65) and liver of rats (66) and guinea pigs (67), while vitamin E deficiency led to an upregulation of CD36 in HepG2 cells (68). This downregulation may be due to a reduction of lipid peroxidation and cellular oxidative stress (69) or to an inhibition of tyrosine kinase (65). Although not demonstrated, such regulation by vitamin E may also involve transcription factors such as PXR $(70,71)$, possibly via its long chain metabolite $\alpha$-tocopherol-13'-COOH (72).

Interestingly, CD36 intestinal expression is downregulated by dietary fat, and especially by fatty acids such as oleic acid $(73,74)$, which can subsequently impact on vitamin $\mathrm{E}$ absorption (Table 1).

Vitamin E and NPC1L1 regulation

If no data are available on vitamin E effect on NPC1L1 expression, it is noteworthy that this protein is regulated by SREBP2 (75) and LXR (76), making it a putative target of tocopherol signaling. Indeed, tocopherol can target these transcription factors in an indirect manner (37).

NPC1L1 is downregulated by several dietary compounds including fat (77), cholesterol (78), fatty acids $(79,57)$, calcium (80), curcumin (81), sitosterol (82) and lactobacillus from fermented foods (83), while dietary glucose was shown to increase its expression (84). NPC1L1 expression is also regulated by hormones: estrogen (85) and cholecystokinin (86) could increase it while PYY reduced it (87). The effects of these factors are summarized in Table 1.

Vitamin $E$ and $A B C$ transporter regulation 
We previously reported in Caco-2 cells that vitamin E, probably via SREBP2, led to an inhibition of cholesterol synthesis, which resulted in a decrease in cellular cholesterol and thus in cellular oxysterol concentration. This induced an important decrease in the expression level of genes regulated by LXR, such as $A B C A 1$ and $A B C G 1$ (88). This effect was confirmed in vivo in rat liver and macrophages (37).

Additionally, as presented in Table 1, intestinal ABCA1 can be downregulated by fat, fatty acids $(79,57)$, phytosterols $(89)$, glucose $(90)$, chokeberry polyphenols $(59)$ or ezetimibe (58). However, the subsequent effect of such regulation on vitamin E absorption still need to be demonstrated. 


\section{Conclusions}

The mechanisms of vitamin E intestinal absorption are only partly comprehended. The discovery of vitamin $\mathrm{E}$ intestinal transporters with broad substrate specificity has raised many questions regarding the potential interactions with other nutrients and/or drugs during the vitamin E absorption process, due to possible competitions or because of indirect effects on transporter expressions. Besides, it is very likely that other proteins involved in vitamin E membrane transport still need to be identified (7), which is of major importance because genetic polymorphisms in these proteins can partly explain the high interindividual variability regarding vitamin E absorption in humans (91). Further research is thus needed to answer these questions and propose personalized intake recommendations for vitamin $\mathrm{E}$ taking into accounts both genetic factors and lifestyle.

Conflicts of Interest: The author declares no conflict of interest. 


\section{References}

1. DellaPenna, D. (2005) A decade of progress in understanding vitamin E synthesis in plants. J Plant Physiol 162, 729-737.

2. Shahidi, F., and de Camargo, A.C. (2016) Tocopherols and Tocotrienols in Common and Emerging Dietary Sources: Occurrence, Applications, and Health Benefits. Int J Mol Sci 17.

3. Martin, A. (2001) Apports nutritionnels conseillés pour la population française. Tec $\mathcal{E}$ Doc Lavoisier $3^{e}$ Ed Paris, 605 pp.

4. Christen, S., Woodall, A.A., Shigenaga, M.K., Southwell-Keely, P.T., Duncan, M.W., et al. (1997) gamma-tocopherol traps mutagenic electrophiles such as $\mathrm{NO}(\mathrm{X})$ and complements alpha-tocopherol: physiological implications. Proc Natl Acad Sci U S A 94, 3217-3222.

5. Azzi, A., Meydani, S.N., Meydani, M., and Zingg, J.M. (2016) The rise, the fall and the renaissance of vitamin E. Arch Biochem Biophys 595, 100-108.

6. Troesch, B., Hoeft, B., McBurney, M., Eggersdorfer, M., and Weber, P. (2012) Dietary surveys indicate vitamin intakes below recommendations are common in representative Western countries. Br J Nutr 108, 692-698.

7. Reboul, E. (2017) Vitamin E Bioavailability: Mechanisms of Intestinal Absorption in the Spotlight. Antioxidants (Basel) 6.

8. Hollander, D., Rim, E., and Muralidhara, K.S. (1975) Mechanism and site of small intestinal absorption of alpha-tocopherol in the rat. Gastroenterology 68, 1492-1499.

9. Jeanes, Y.M., Hall, W.L., and Lodge, J.K. (2005) Comparative (2)H-labelled alpha-tocopherol biokinetics in plasma, lipoproteins, erythrocytes, platelets and lymphocytes in normolipidaemic males. British Journal of Nutrition 94, 92-99.

10. Reboul, E., Klein, A., Bietrix, F., Gleize, B., Malezet-Desmoulins, C., et al. (2006) Scavenger receptor class B type I (SR-BI) is involved in vitamin E transport across the enterocyte. J Biol Chem 281, 4739-4745.

11. Goti, D., Reicher, H., Malle, E., Kostner, G.M., Panzenboeck, U., et al. (1998) High-density lipoprotein (HDL3)-associated alpha-tocopherol is taken up by HepG2 cells via the selective uptake pathway and resecreted with endogenously synthesized apo-lipoprotein B-rich lipoprotein particles. Biochemical Journal 332, 57-65. 
12. Goti, D., Hrzenjak, A., Levak-Frank, S., Frank, S., van der Westhuyzen, D.R., et al. (2001) Scavenger receptor class B, type I is expressed in porcine brain capillary endothelial cells and contributes to selective uptake of HDL-associated vitamin E. J Neurochem 76, 498-508.

13. Tachikawa, M., Okayasu, S., and Hosoya, K. (2007) Functional involvement of scavenger receptor class B, type $\mathrm{I}$, in the uptake of alpha-tocopherol using cultured rat retinal capillary endothelial cells. Mol Vis 13, 2041-2047.

14. Kolleck, I., Schlame, M., Fechner, H., Looman, A.C., Wissel, H., et al. (1999) HDL is the major source of vitamin E for type II pneumocytes. Free Radic Biol Med 27, 882-890.

15. Mardones, P., Strobel, P., Miranda, S., Leighton, F., Quinones, V., et al. (2002) Alpha-tocopherol metabolism is abnormal in scavenger receptor class B type I (SR-BI)-deficient mice. J Nutr 132, 443449.

16. Voolstra, O., Kiefer, C., Hoehne, M., Welsch, R., Vogt, K., et al. (2006) The Drosophila class B scavenger receptor NinaD-I is a cell surface receptor mediating carotenoid transport for visual chromophore synthesis. Biochemistry 45, 13429-13437.

17. Reboul, E., Soayfane, Z., Goncalves, A., Cantiello, M., Bott, R., et al. (2012) Respective contributions of intestinal Niemann-Pick C1-like 1 and scavenger receptor class B type I to cholesterol and tocopherol uptake: in vivo v. in vitro studies. Br J Nutr 107, 1296-1304.

18. Hansen, G.H., Niels-Christiansen, L.L., Immerdal, L., and Danielsen, E.M. (2003) Scavenger receptor class B type I (SR-BI) in pig enterocytes: trafficking from the brush border to lipid droplets during fat absorption. Gut 52, 1424-1431.

19. Goncalves, A., Gontero, B., Nowicki, M., Margier, M., Masset, G., et al. (2015) Micellar lipid composition affects micelle interaction with class B scavenger receptor extracellular loops. J Lipid Res 56, 1123-1133.

20. Beaslas, O., Cueille, C., Delers, F., Chateau, D., Chambaz, J., et al. (2009) Sensing of dietary lipids by enterocytes: a new role for SR-BI/CLA-1. PLoS One 4, e4278.

21. Briand, O., Touche, V., Colin, S., Brufau, G., Davalos, A., et al. (2016) Liver X Receptor Regulates Triglyceride Absorption Through Intestinal Down-regulation of Scavenger Receptor Class B, Type 1. Gastroenterology 150, 650-658. 
22. Borel, P., Lietz, G., Goncalves, A., Szabo de Edelenyi, F., Lecompte, S., et al. (2013) CD36 and SRBI Are Involved in Cellular Uptake of Provitamin A Carotenoids by Caco-2 and HEK Cells, and Some of Their Genetic Variants Are Associated with Plasma Concentrations of These Micronutrients in Humans. J Nutr 143, 448-456.

23. Reboul, E., Goncalves, A., Comera, C., Bott, R., Nowicki, M., et al. (2011) Vitamin D intestinal absorption is not a simple passive diffusion: evidences for involvement of cholesterol transporters. Mol Nutr Food Res 55, 691-702.

24. Goncalves, A., Margier, M., Roi, S., Collet, X., Niot, I., et al. (2014) Intestinal scavenger receptors are involved in vitamin K1 absorption. J Biol Chem 289, 30743-30752.

25. Goncalves, A., Roi, S., Nowicki, M., Niot, I., and Reboul, E. (2014) Cluster-determinant 36 (CD36) impacts on vitamin E postprandial response. Mol Nutr Food Res 58, 2297-2306.

26. Narushima, K., Takada, T., Yamanashi, Y., and Suzuki, H. (2008) Niemann-pick C1-like 1 mediates alpha-tocopherol transport. Mol Pharmacol 74, 42-49.

27. Yamanashi, Y., Takada, T., and Suzuki, H. (2009) In-vitro characterization of the six clustered variants of NPC1L1 observed in cholesterol low absorbers. Pharmacogenet Genomics 19, 884-892.

28. Kamishikiryo, J., Haraguchi, M., Nakashima, S., Tasaka, Y., Narahara, H., et al. (2017) N-terminal domain of the cholesterol transporter Niemann-Pick C1-like 1 (NPC1L1) is essential for alphatocopherol transport. Biochem Biophys Res Commun 486, 476-480.

29. Alqahtani, S., Qosa, H., Primeaux, B., and Kaddoumi, A. (2015) Orlistat limits cholesterol intestinal absorption by Niemann-pick C1-like 1 (NPC1L1) inhibition. Eur J Pharmacol 762, 263-269.

30. Irías-Mata, A., Sus, N., Flory, S., Stock, D., Woerner, D., et al. (2018) $\alpha$-Tocopherol transfer protein does not regulate the cellular uptake and intracellular distribution of $\alpha$ - and $\gamma$-tocopherols and -tocotrienols in cultured liver cells. Redox Biology 19, 28-36.

31. Zingg, J.M., Kempna, P., Paris, M., Reiter, E., Villacorta, L., et al. (2008) Characterization of three human sec14p-like proteins: alpha-tocopherol transport activity and expression pattern in tissues. Biochimie 90, 1703-1715.

32. Anwar, K., Kayden, H.J., and Hussain, M.M. (2006) Transport of vitamin E by differentiated Caco-2 cells. J Lipid Res 47, 1261-1273. 
33. Reboul, E., Trompier, D., Moussa, M., Klein, A., Landrier, J.F., et al. (2009) ATP-binding cassette transporter A1 is significantly involved in the intestinal absorption of alpha- and gamma-tocopherol but not in that of retinyl palmitate in mice. Am J Clin Nutr 89, 177-184.

34. Nicod, N., and Parker, R.S. (2013) Vitamin E secretion by Caco-2 monolayers to APOA1, but not to HDL, is vitamer selective. J Nutr 143, 1565-1572.

35. Oram, J.F., Vaughan, A.M., and Stocker, R. (2001) ATP-binding cassette transporter A1 mediates cellular secretion of alpha-tocopherol. J Biol Chem 276, 39898-39902.

36. Shichiri, M., Takanezawa, Y., Rotzoll, D.E., Yoshida, Y., Kokubu, T., et al. (2010) ATP-binding cassette transporter A1 is involved in hepatic alpha-tocopherol secretion. J Nutr Biochem 21, 451-456.

37. Olivier, M., Bott, G.R., Frisdal, E., Nowick, M., Plengpanich, W., et al. (2014) ABCG1 is involved in vitamin E efflux. Biochim Biophys Acta 1841, 1741-1751.

38. Reboul, E., Dyka, F.M., Quazi, F., and Molday, R.S. (2013) Cholesterol transport via ABCA1: new insights from solid-phase binding assay. Biochimie 95, 957-961.

39. Reboul, E., and Borel, P. (2011) Proteins involved in uptake, intracellular transport and basolateral secretion of fat-soluble vitamins and carotenoids by mammalian enterocytes. Prog Lipid Res 50, 388-402.

40. Goncalves, A., Roi, S., Nowicki, M., Dhaussy, A., Huertas, A., et al. (2015) Fat-soluble vitamin intestinal absorption: absorption sites in the intestine and interactions for absorption. Food Chem 172, 155-160.

41. Bietrix, F., Yan, D., Nauze, M., Rolland, C., Bertrand-Michel, J., et al. (2006) Accelerated lipid absorption in mice overexpressing intestinal SR-BI. J Biol Chem 281, 7214-7219.

42. Nassir, F., Wilson, B., Han, X., Gross, R.W., and Abumrad, N.A. (2007) CD36 is important for fatty acid and cholesterol uptake by the proximal but not distal intestine. J Biol Chem 282, 19493-19501.

43. Altmann, S.W., Davis, H.R., Jr., Zhu, L.J., Yao, X., Hoos, L.M., et al. (2004) Niemann-Pick C1 Like 1 protein is critical for intestinal cholesterol absorption. Science 303, 1201-1204.

44. Masson, C.J., Plat, J., Mensink, R.P., Namiot, A., Kisielewski, W., et al. (2010) Fatty acid- and cholesterol transporter protein expression along the human intestinal tract. PLoS One 5, e10380.

45. Cai, S.F., Kirby, R.J., Howles, P.N., and Hui, D.Y. (2001) Differentiation-dependent expression and localization of the class B type I scavenger receptor in intestine. J Lipid Res 42, 902-909. 
46. Traber, M.G., and Kayden, H.J. (1989) Preferential incorporation of alpha-tocopherol vs gammatocopherol in human lipoproteins. Am J Clin Nutr 49, 517-526.

47. Traber, M.G., Burton, G.W., Ingold, K.U., and Kayden, H.J. (1990) RRR- and SRR-alphatocopherols are secreted without discrimination in human chylomicrons, but RRR-alpha-tocopherol is preferentially secreted in very low density lipoproteins. J Lipid Res 31, 675-685.

48. Porsgaard, T., and Hoy, C.E. (2000) Absorption by rats of tocopherols present in edible vegetable oils. Lipids 35, 1073-1078.

49. Bardowell, S.A., Ding, X., and Parker, R.S. (2012) Disruption of P450-mediated vitamin E hydroxylase activities alters vitamin E status in tocopherol supplemented mice and reveals extrahepatic vitamin E metabolism. J Lipid Res 53, 2667-2676.

50. Bruno, R.S., Leonard, S.W., Park, S.I., Zhao, Y., and Traber, M.G. (2006) Human vitamin E requirements assessed with the use of apples fortified with deuterium-labeled alpha-tocopheryl acetate. Am J Clin Nutr 83, 299-304.

51. Novotny, J.A., Fadel, J.G., Holstege, D.M., Furr, H.C., and Clifford, A.J. (2012) This kinetic, bioavailability, and metabolism study of RRR-alpha-tocopherol in healthy adults suggests lower intake requirements than previous estimates. J Nutr 142, 2105-2111.

52. Sklan, D., and Donoghue, S. (1982) Vitamin E response to high dietary vitamin A in the chick. J Nutr 112, 759-765.

53. Richelle, M., Enslen, M., Hager, C., Groux, M., Tavazzi, I., et al. (2004) Both free and esterified plant sterols reduce cholesterol absorption and the bioavailability of beta-carotene and alphatocopherol in normocholesterolemic humans. Am J Clin Nutr 80, 171-177.

54. Reboul, E., Thap, S., Perrot, E., Amiot, M.J., Lairon, D., et al. (2007) Effect of the main dietary antioxidants (carotenoids, gamma-tocopherol, polyphenols, and vitamin C) on alpha-tocopherol absorption. Eur J Clin Nutr.

55. Griffiths, D.W. (1986) The inhibition of digestive enzymes by polyphenolic compounds. Advances in experimental medicine and biology 199, 509-516.

56. Witt, W., Kolleck, I., Fechner, H., Sinha, P., and Rustow, B. (2000) Regulation by vitamin E of the scavenger receptor BI in rat liver and HepG2 cells. J Lipid Res 41, 2009-2016. 
57. Goncalves, A., Gleize, B., Roi, S., Nowicki, M., Dhaussy, A., et al. (2013) Fatty acids affect micellar properties and modulate vitamin D uptake and basolateral efflux in Caco-2 cells. J Nutr Biochem 24, $1751-1757$.

58. During, A., Dawson, H.D., and Harrison, E.H. (2005) Carotenoid Transport Is Decreased and Expression of the Lipid Transporters SR-BI, NPC1L1, and ABCA1 Is Downregulated in Caco-2 Cells Treated with Ezetimibe. J Nutr 135, 2305-2312.

59. Kim, B., Park, Y., Wegner, C.J., Bolling, B.W., and Lee, J. (2013) Polyphenol-rich black chokeberry (Aronia melanocarpa) extract regulates the expression of genes critical for intestinal cholesterol flux in Caco-2 cells. J Nutr Biochem 24, 1564-1570.

60. Lobo, G.P., Hessel, S., Eichinger, A., Noy, N., Moise, A.R., et al. (2010) ISX is a retinoic acidsensitive gatekeeper that controls intestinal beta,beta-carotene absorption and vitamin A production. FASEB Journal 24, 1656-1666.

61. Hayashi, A.A., Webb, J., Choi, J., Baker, C., Lino, M., et al. (2011) Intestinal SR-BI is upregulated in insulin-resistant states and is associated with overproduction of intestinal apoB48-containing lipoproteins. Am J Physiol Gastrointest Liver Physiol 301, G326-337.

62. Voshol, P.J., Schwarz, M., Rigotti, A., Krieger, M., Groen, A.K., et al. (2001) Down-regulation of intestinal scavenger receptor class B, type I (SR-BI) expression in rodents under conditions of deficient bile delivery to the intestine. Biochem J 356, 317-325.

63. Azzi, A., Breyer, I., Feher, M., Pastori, M., Ricciarelli, R., et al. (2000) Specific cellular responses to alpha-tocopherol. J Nutr 130, 1649-1652.

64. Ricciarelli, R., Zingg, J.M., and Azzi, A. (2000) Vitamin E reduces the uptake of oxidized LDL by inhibiting CD36 scavenger receptor expression in cultured aortic smooth muscle cells. Circulation 102, $82-87$.

65. Venugopal, S.K., Devaraj, S., and Jialal, I. (2004) RRR-alpha-tocopherol decreases the expression of the major scavenger receptor, CD36, in human macrophages via inhibition of tyrosine kinase (Tyk2). Atherosclerosis 175, 213-220.

66. Barella, L., Muller, P.Y., Schlachter, M., Hunziker, W., Stocklin, E., et al. (2004) Identification of hepatic molecular mechanisms of action of alpha-tocopherol using global gene expression profile analysis in rats. Biochim Biophys Acta 1689, 66-74. 
67. Podszun, M.C., Grebenstein, N., Spruss, A., Schlueter, T., Kremoser, C., et al. (2014) Dietary alpha-tocopherol and atorvastatin reduce high-fat-induced lipid accumulation and down-regulate CD36 protein in the liver of guinea pigs. J Nutr Biochem 25, 573-579.

68. Rimbach, G., Fischer, A., Stoecklin, E., and Barella, L. (2004) Modulation of hepatic gene expression by alpha-tocopherol in cultured cells and in vivo. Ann N Y Acad Sci 1031, 102-108.

69. Fuhrman, B., Volkova, N., and Aviram, M. (2002) Oxidative stress increases the expression of the CD36 scavenger receptor and the cellular uptake of oxidized low-density lipoprotein in macrophages from atherosclerotic mice: protective role of antioxidants and of paraoxonase. Atherosclerosis 161, 307-316.

70. Traber, M.G. (2004) Vitamin E, nuclear receptors and xenobiotic metabolism. Arch Biochem Biophys 423, 6-11.

71. Zhou, J., Febbraio, M., Wada, T., Zhai, Y., Kuruba, R., et al. (2008) Hepatic fatty acid transporter Cd36 is a common target of LXR, PXR, and PPARgamma in promoting steatosis. Gastroenterology 134, 556-567.

72. Podszun, M.C., Jakobi, M., Birringer, M., Weiss, J., and Frank, J. (2017) The long chain $\alpha-$ tocopherol metabolite $\alpha-13^{\prime}-\mathrm{COOH}$ and $\gamma$-tocotrienol induce P-glycoprotein expression and activity by activation of the pregnane $\mathrm{X}$ receptor in the intestinal cell line LS 180. Molecular Nutrition \& Food Research 61, 1600605.

73. Poirier, H., Degrace, P., Niot, I., Bernard, A., and Besnard, P. (1996) Localization and regulation of the putative membrane fatty-acid transporter (FAT) in the small intestine - Comparison with fatty acid-binding proteins (FABP). European Journal of Biochemistry 238, 368-373 AF P BesnardUniv BourgogneLab Physiol NutrEa Dred 580Ensbana361 Esplanade ErasmeF-21000 Dijon, France DO Article LA English.

74. Chen, M., Yang, Y., Braunstein, E., Georgeson, K.E., and Harmon, C.M. (2001) Gut expression and regulation of FAT/CD36: possible role in fatty acid transport in rat enterocytes. Am J Physiol Endocrinol Metab 281, E916-923.

75. Alrefai, W.A., Annaba, F., Sarwar, Z., Dwivedi, A., Saksena, S., et al. (2007) Modulation of human Niemann-Pick C1-like 1 gene expression by sterol: Role of sterol regulatory element binding protein 2. Am J Physiol Gastrointest Liver Physiol 292, G369-376. 
76. Bonamassa, B., and Moschetta, A. (2013) Atherosclerosis: lessons from LXR and the intestine. Trends Endocrinol Metab 24, 120-128.

77. de Vogel-van den Bosch, H.M., de Wit, N.J., Hooiveld, G.J., Vermeulen, H., van der Veen, J.N., et al. (2008) A cholesterol-free, high-fat diet suppresses gene expression of cholesterol transporters in murine small intestine. Am J Physiol Gastrointest Liver Physiol 294, G1171-1180.

78. Davis, H.R., Jr., Zhu, L.J., Hoos, L.M., Tetzloff, G., Maguire, M., et al. (2004) Niemann-Pick C1 Like 1 (NPC1L1) is the intestinal phytosterol and cholesterol transporter and a key modulator of whole-body cholesterol homeostasis. J Biol Chem 279, 33586-33592.

79. Alvaro, A., Rosales, R., Masana, L., and Vallve, J.C. (2010) Polyunsaturated fatty acids downregulate in vitro expression of the key intestinal cholesterol absorption protein NPC1L1: no effect of monounsaturated nor saturated fatty acids. J Nutr Biochem 21, 518-525.

80. Ma, K.Y., Yang, N., Jiao, R., Peng, C., Guan, L., et al. (2011) Dietary calcium decreases plasma cholesterol by down-regulation of intestinal Niemann-Pick C1 like 1 and microsomal triacylglycerol transport protein and up-regulation of CYP7A1 and ABCG 5/8 in hamsters. Mol Nutr Food Res 55, $247-258$.

81. Feng, D., Zou, J., Zhang, S., Li, X., and Lu, M. (2017) Hypocholesterolemic Activity of Curcumin Is Mediated by Down-regulating the Expression of Niemann-Pick C1-like 1 in Hamsters. J Agric Food Chem 65, 276-280.

82. Jesch, E.D., Seo, J.M., Carr, T.P., and Lee, J.Y. (2009) Sitosterol reduces messenger RNA and protein expression levels of Niemann-Pick C1-like 1 in FHs 74 Int cells. Nutr Res 29, 859-866.

83. Huang, Y., Wang, J., Quan, G., Wang, X., Yang, L., et al. (2014) Lactobacillus acidophilus ATCC 4356 prevents atherosclerosis via inhibition of intestinal cholesterol absorption in apolipoprotein Eknockout mice. Appl Environ Microbiol 80, 7496-7504.

84. Malhotra, P., Boddy, C.S., Soni, V., Saksena, S., Dudeja, P.K., et al. (2013) D-Glucose modulates intestinal Niemann-Pick C1-like 1 (NPC1L1) gene expression via transcriptional regulation. Am J Physiol Gastrointest Liver Physiol 304, G203-210.

85. Duan, L.P., Wang, H.H., Ohashi, A., and Wang, D.Q. (2006) Role of intestinal sterol transporters Abcg5, Abcg8, and Npc111 in cholesterol absorption in mice: gender and age effects. Am J Physiol Gastrointest Liver Physiol 290, G269-276. 
86. Zhou, L., Yang, H., Okoro, E.U., and Guo, Z. (2014) Up-regulation of cholesterol absorption is a mechanism for cholecystokinin-induced hypercholesterolemia. J Biol Chem 289, 12989-12999.

87. Grenier, E., Garofalo, C., Delvin, E., and Levy, E. (2012) Modulatory role of PYY in transport and metabolism of cholesterol in intestinal epithelial cells. PLoS One 7, e40992.

88. Landrier, J.F., Gouranton, E., Reboul, E., Cardinault, N., El Yazidi, C., et al. (2010) Vitamin E decreases endogenous cholesterol synthesis and apo-AI-mediated cholesterol secretion in Caco-2 cells. J Nutr Biochem.

89. Brauner, R., Johannes, C., Ploessl, F., Bracher, F., and Lorenz, R.L. (2012) Phytosterols reduce cholesterol absorption by inhibition of 27-hydroxycholesterol generation, liver $\mathrm{X}$ receptor alpha activation, and expression of the basolateral sterol exporter ATP-binding cassette A1 in Caco-2 enterocytes. J Nutr 142, 981-989.

90. Boztepe, T., and Gulec, S. (2018) Investigation of the influence of high glucose on molecular and genetic responses: an in vitro study using a human intestine model. Genes $\mathcal{E}$ nutrition 13, 11.

91. Borel, P., Desmarchelier, C., Nowicki, M., Bott, R., and Tourniaire, F. (2015) Can genetic variability in alpha-tocopherol bioavailability explain the heterogeneous response to alphatocopherol supplements? Antioxidants $\mathcal{E}$ redox signaling 22, 669-678. 


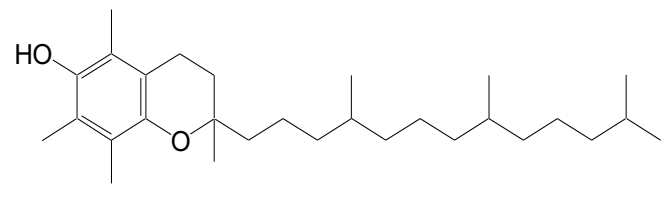

RRR- $\alpha$-tocopherol<smiles>Cc1cc(O)c(C)c2c1OC(C)(CCCC(C)CCCC(C)CCCC(C)C)CC2</smiles>

RRR- $\beta$-tocopherol<smiles>Cc1c(O)cc2c(c1C)OC(C)(CCCC(C)CCCC(C)CCCC(C)C)CC2</smiles>

RRR- $\delta$-tocopherol<smiles>Cc1cc(O)cc2c1OC(C)(CCCC(C)CCCC(C)CCCC(C)C)CC2</smiles>

RRR- $\gamma$-tocopherol<smiles>CC(C)=CCC/C(C)=C/CC/C(C)=C/CCC1(C)CCc2c(C)c(O)c(C)c(C)c2O1</smiles>

$\alpha$-tocotrienol<smiles>CC(C)=CCC/C(C)=C/CC/C(C)=C/CCC1(C)CCc2c(C)c(O)cc(C)c2O1</smiles>

$\beta$-tocotrienol<smiles>CC(C)=CCC/C(C)=C/CC/C(C)=C/CCC1(C)CCc2cc(O)c(C)c(C)c2O1</smiles>

$\delta$-tocotrienol<smiles>CC(C)=CCC/C(C)=C/CC/C(C)=C/CCC1(C)CCc2cc(O)cc(C)c2O1</smiles>

$\gamma$-tocotrienol

Figure 1. The vitamin E family 


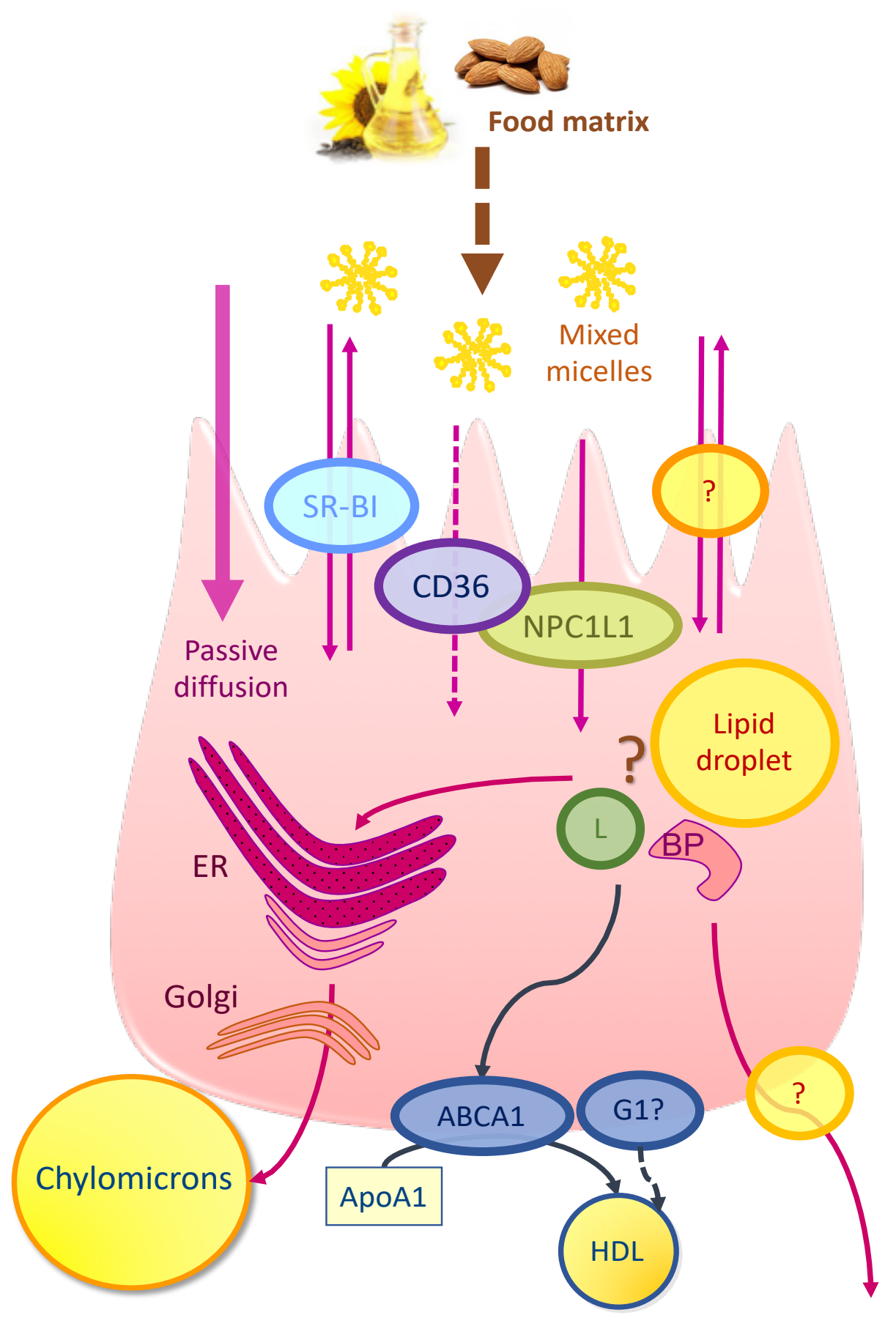

\section{Figure 2: Vitamin $\mathrm{E}$ fate across the enterocyte}

$?=$ putative pathways, --> Indirect transport, $\mathrm{L}=$ lysosomes, $\mathrm{BP}=$ binding protein, $\mathrm{ER}=$ endoplasmic reticulum

Vitamin E is released from its food matrix during digestion and incorporated into mixed micelles. Micellar vitamin E apical transport is facilitated by membrane proteins including SR-BI, CD36 and NPC1L1. A fraction of vitamin E may be effluxed back to the intestinal lumen via apical membrane transporters (SR-BI and possibly other transporters). Intracellular vitamin E might be associated to lipid droplets, lysosomes, ER membrane and/ or specific binding proteins. The major fraction of vitamin $\mathrm{E}$ is secreted in the lymph into chylomicrons, while a minor part may also be secreted at the basolateral side via ABCA1 (apoAI pathway) and possibly ABCG1. 
Table 1. Factors modulating intestinal transporter expression 


\begin{tabular}{|c|c|c|c|c|c|c|}
\hline \multicolumn{2}{|c|}{ Factors } & $\begin{array}{l}\text { Membrane } \\
\text { transporter }\end{array}$ & Model & Effect & $\begin{array}{c}\text { Signaling/ regulation } \\
\text { pathway }\end{array}$ & References \\
\hline \multirow{26}{*}{ 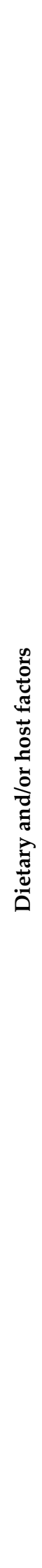 } & \multirow{5}{*}{ Vitamin E } & SR-BI & $\begin{array}{c}\text { Rat liver/ } \\
\text { HepG2 cells }\end{array}$ & \multirow{4}{*}{$\downarrow$} & PKC? & $(54)$ \\
\hline & & \multirow[t]{3}{*}{ CD36 } & $\begin{array}{c}\text { Rat liver/ guinea } \\
\text { pig liver }\end{array}$ & & $\begin{array}{c}\text { Independent of LXR } \alpha, \text { PXR } \\
\text { and PPAR } \gamma \text {. Posttranslational } \\
\text { regulation? }\end{array}$ & $(64,65)$ \\
\hline & & & Macrophages & & Tyrosine kinase (Tyk2). & $(63)$ \\
\hline & & & Muscle cells & & nd & $(62)$ \\
\hline & & ABCA1/G1 & Caco-2 cells & $\downarrow$ & $\begin{array}{l}\text { SREBP2, cholesterol } \\
\text { synthesis genes, LXR }\end{array}$ & $(85)$ \\
\hline & & CD36 & Mouse intestine & $\downarrow$ & nd & $(70)$ \\
\hline & Fat & NPC1L1 & & & Linked to a posttranslational & \\
\hline & & ABCA1 & & 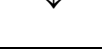 & increase in HMGCR activity & $(7)$ \\
\hline & Oleic acid and EPA & SR-BI & Caco-2 & $\uparrow$ & nd & $(55)$ \\
\hline & Oleic acid & CD36 & Rat enterocytes & $\downarrow$ & nd & $(71)$ \\
\hline & EPA, DHA & NPC1L1 & Caco- 2 cells & $\downarrow$ & LXR/RXR? & \multirow{2}{*}{$(76,55)$} \\
\hline & ARA, DHA & ABCA1 & Caco-2 cells & $\downarrow$ & LXR/RXR? & \\
\hline & cholesterol & NPC1L1 & Mouse intestine & $\downarrow$ & nd & $(75)$ \\
\hline & $\begin{array}{c}25- \\
\text { hydroxycholesterol }\end{array}$ & NPC1L1 & Caco-2 cells & $\downarrow$ & SREBP-2 & $(72)$ \\
\hline & Sitosterol & NPC1L1 & $\begin{array}{c}\text { FHs } 74 \text { intestinal } \\
\text { cells } \\
\end{array}$ & $\downarrow$ & nd & $(79)$ \\
\hline & Phytosterols & ABCA1 & Caco-2 cells & $\downarrow$ & 27 hydroxycholesterol/ LXR $\alpha$ & $(86)$ \\
\hline & \multirow[t]{2}{*}{ Glucose } & NPC1L1 & $\begin{array}{l}\text { Caco-2 cells, } \\
\text { mice }\end{array}$ & $\uparrow$ & $\begin{array}{l}\text { Phosphatase-dependent } \\
\text { transcriptional pathways }\end{array}$ & $(81)$ \\
\hline & & ABCA1 & Caco-2 cells & $\downarrow$ & nd & $(87)$ \\
\hline & Calcium & NPC1L1 & $\begin{array}{c}\text { Ovariectomized } \\
\text { hamsters }\end{array}$ & $\downarrow$ & $\begin{array}{c}\text { Independent of SREBP2, } \\
\text { LXR and HMGCR }\end{array}$ & $(77)$ \\
\hline & \multirow{3}{*}{$\begin{array}{l}\text { Polyphenols } \\
\text { (chockeberry) }\end{array}$} & SR-BI & \multirow{3}{*}{ Caco-2 cells } & \multirow{3}{*}{$\downarrow$} & \multirow{3}{*}{$\begin{array}{c}\text { HMGCR, SREBP2, } \\
\text { SREBP1C? }\end{array}$} & \multirow{3}{*}{$(57)$} \\
\hline & & NPC1L1 & & & & \\
\hline & & ABCA1 & & & & \\
\hline & Curcumin & NPC1L1 & $\begin{array}{l}\text { Hamster } \\
\text { intestine }\end{array}$ & $\downarrow$ & SREBP2? & $(78)$ \\
\hline & Retinoid & SR-BI & Mouse/cell lines & $\downarrow$ & ISX & $(58)$ \\
\hline & $\begin{array}{c}\text { Lactobacillus } \\
\text { plantarum Lp27 }\end{array}$ & NPC1L1 & $\begin{array}{c}\text { Caco- } 2 \text { cells, rat } \\
\text { intestine }\end{array}$ & $\downarrow$ & nd & $(80)$ \\
\hline & Bile salts & SR-BI & $\begin{array}{l}\text { Mouse and rat } \\
\text { intestines }\end{array}$ & $\uparrow$ & $\begin{array}{c}\text { Postranscriptionnal } \\
\text { regulation }\end{array}$ & $(60)$ \\
\hline
\end{tabular}




\begin{tabular}{|c|c|c|c|c|c|c|}
\hline \multirow{4}{*}{ 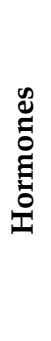 } & Insulin resistance & SR-BI & $\begin{array}{l}\text { Hamster } \\
\text { intestine }\end{array}$ & $\uparrow$ & nd & (59) \\
\hline & Estrogen & NPC1L1 & Mouse intestine & $\uparrow$ & $\mathrm{ER} \alpha$ & $(82)$ \\
\hline & Cholecystokinin & NPC1L1 & $\begin{array}{c}\text { Mouse intestine, } \\
\text { Caco- } 2 \text { cells }\end{array}$ & $\uparrow$ & $\begin{array}{c}\text { CCK1R/CCK2R, G } \beta \gamma, \text { PI3K, } \\
\text { Akt, Rab11a }\end{array}$ & (83) \\
\hline & PYY & NPC1L1 & Caco-2 cells & $\downarrow$ & nd & $(84)$ \\
\hline \multirow{3}{*}{$\stackrel{\infty}{D}_{D}^{\infty 00}$} & \multirow{3}{*}{ Ezetimibe } & SR-BI & \multirow{3}{*}{ Caco-2 cells } & \multirow{3}{*}{$\downarrow$} & \multirow{3}{*}{$\begin{array}{c}\text { RAR } \gamma, \text { SREBP-1 and }-2, \\
\text { LXR } \beta \text { ? }\end{array}$} & \multirow{3}{*}{$(56)$} \\
\hline & & NPC1L1 & & & & \\
\hline & & ABCA1 & & & & \\
\hline
\end{tabular}

nd = not described, ecosapentaenoic acid (EPA), arachidonic acid (ARA), docohexaenoic acid (DHA), 3-hydroxy-3-methylglutaryl coenzyme A reductase (HMGCR), CCK receptor 1 and 2 (CCK1R and CCK2R), G protein $\beta \gamma$ dimer $(G \beta \gamma)$, phosphatidylinositide 3-kinase (PI3K) 